\title{
Toughness and Impact Strength in Dynamic Bending of Wood as a Function of the Modulus of Elasticity and the Strength in Compression to the Grain
}

\author{
Aline Pinto Moreira ${ }^{1}$, Emily da Silveira ${ }^{1}$, Diego Henrique de Almeida ${ }^{1}$, Tiago Hendrigo de Almeida ${ }^{2}$, \\ Tulio Hallak Panzera ${ }^{3}$, André Luís Christoforo ${ }^{1, *}$, Francisco Antonio Rocco ${ }^{4}$
}

\begin{abstract}
${ }^{1}$ Centre for Innovation and Technology in Composites (CITeC), Department of Civil Engineering (DECiv), Federal University of São Carlos (UFSCar), São Carlos, Brazil

${ }^{2}$ Department of Materials Engineering (SMM), Engineering School of São Carlos (EESC), São Paulo University (USP), São Carlos, Brazil

${ }^{3}$ Centre for Innovation and Technology in Composites (CITeC), Department of Mechanical Engineering, Federal University of São João del-Rei, São João del-Rei, Brazil

${ }^{4}$ Department of Structures Engineering (SET), Engineering School of São Carlos (EESC), São Paulo University (USP), São Carlos, Brazil
\end{abstract}

\begin{abstract}
Toughness is the mechanical property that determines the wood strength when a force acts in a short time interval. Its value is determined in the bending impact test. Timber has to resist to impact forces in several applications, nevertheless this property is not widely studied to tropical wood species from Brazil. This study aimed to correlate the toughness and the impact strength of wood with the modulus of elasticity and the strength in the compression parallel to grain test. Therefore ten tropical species, from different strength classes, grown in Brazil were tested according to the Brazilian Standard Code ABNT NBR 7190:1997. The studied species were: Cedro (Cedrella sp.), Cambará Rosa (Erisma uncinatum Warm), Cedrorana (Cedrelinga cateniformis), Catanudo (Calophyllum sp.), Cupiúba (Goupia glabra), Angelim Saia (Parkia spp.), Tatajuba (Bagassa guianensis Aubl.), Guaiçara (Luetzelburgia sp.), Cumaru (Dipteryx odorata) and Angelim Vermelho (Dinizia excelsa Ducke). It was developed a relation between the studied properties through regression models, evaluated according to the variance analysis (ANOVA). The results of the statistical analysis revealed led to the conclusion that there is no correlation between the proposed properties for the analyzed species.
\end{abstract}

Keywords Compression strength parallel to grain, Toughness, Impact strength, Regression models, Analysis of variance

\section{Introduction}

Wood is a natural material, renewable and abundant in Brazil. The called "Amazônia Legal" is approximately five millions square kilometers long, which corresponds to $59 \%$ of the Brazilian territory. The rain forest covers around $63 \%$ of this area. The proper use of the wood ensures the forest recovery, ensuring a continuous supply $[1,2]$.

As an engineering material wood is used in roof structures, frames, floors and finishing in Brazil. Besides that, it is used in the execution phase of buildings in construction sites, scaffolding, palisade hoarding and formwork. Nevertheless, the industry lacks consolidated information regarding the quality and performance of Brazilian wood species, which leads to its irrational use $[3,4]$.

Despite the advantages of the use of wood as a construction material, in Brazil it is not widely used. Due to

* Corresponding author:

alchristoforo@gmail.com (André Luís Christoforo)

Published online at http://journal.sapub.org/ijme

Copyright (C) 2017 Scientific \& Academic Publishing. All Rights Reserved the tradition, reinforced concrete and steel structures are more used in the constructions of the country. Furthermore, the disregard for timber comes from the lack of information and the misuse of the material, mostly due to the lack of emphasis given to its applications in engineering and architecture courses [5].

The Brazilian Standard Code ABNT NBR 7190:1997 [6] sets the design criteria of timber structures, as well as the procedures to evaluate physical and mechanical properties of woods.

Kollmann and Côté [7] define that a stress caused by an impact acts in a short time interval. A bean has a greater load bearing capacity to resist to a shock of a suddenly applied load than when a static forces acts. The impact resistance is expressed as the energy absorbed by a specimen.

Bodig and Jayne [8] express toughness as the energy required to cause the complete failure of a specimen. The greater the impact strength of the specimen the grater is its toughness value.

Timber members in service can be subjected to impact loads when used in baseball batons, bridges, gun cables, railway ties, beams, formwork, silos and packaging, for 
examples. In this cases, timber members have more chances to failure when subjected to impact stresses than by stresses from static loads [9-12].

It is worth mentioning that, in order to perform the impact bending test, it is necessary to use a very specific equipment, the called impact machine. This machine is rarely found in the Brazilian's research centers. Thus, it is identified the importance of the development of research in the search of estimating the toughness in function of other properties of the wood [13-16].

The impact bending test defines the material brittleness when stress beyond the proportional limit is applied [17]. There are several types of machines used on the test, as the Charpy and Izod. According to the Charpy test, the toughness value is determined based on the pendulum movement (Fig. 1). The system consists of a rod and the pendulum head acts like a body of weigh $\mathrm{B}$, located at a distance 1 from the rotation axis $\mathrm{O}$, at point $\mathrm{C}$. At the beginning of the test, the mass center is at an initial high $\left(\mathrm{h}_{\mathrm{i}}\right)$ from the point $\mathrm{A}$. When free loosely the pendulum reaches a maximum high $\mathrm{h}_{0}, \mathrm{~h}_{0}<\mathrm{h}_{\mathrm{i}}$ due to the friction.

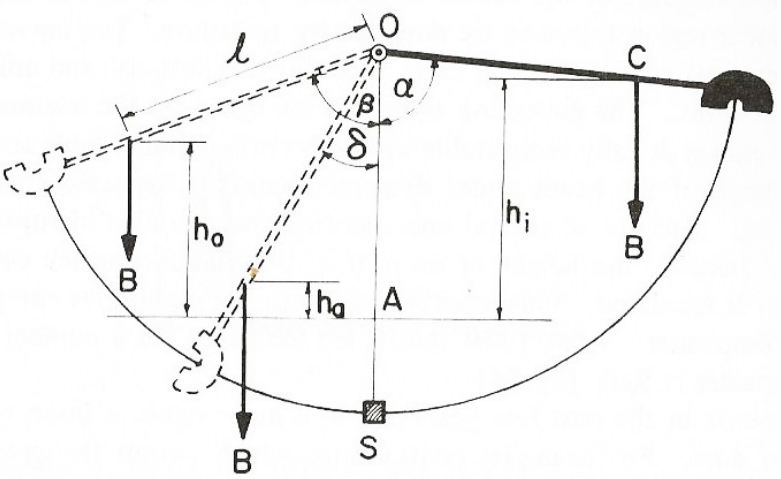

Figure 1. Pendulum impact used for the toughness value determination [8]

The energy that causes the completely failure is the difference from the energy before and after the pendulum touches the specimen $\mathrm{S}$. After the failure, the $\mathrm{C}_{\mathrm{s}}$ high reduces to $h_{a}$. The toughness (T) value can be determined using Eq. 1, were $\mathrm{K}_{0}$ e $\mathrm{K}_{\mathrm{a}}$ are the initial and final pendulum kinetic energy, respectively.

$$
\mathrm{T}=\mathrm{K}_{0}-\mathrm{K}_{\mathrm{a}}
$$

The kinetic energy (W) necessary to causes the specimen rupture can be expressed as the variation of the potential energy of the pendulum (Eq. 2).

$$
\mathrm{T}=\mathrm{W}=\mathrm{B} \cdot \mathrm{h}_{0}-\mathrm{B} \cdot \mathrm{h}_{\mathrm{a}}=\mathrm{B} \cdot\left(\mathrm{h}_{0}-\mathrm{h}_{\mathrm{a}}\right)
$$

Eq. 3 and Eq. 4 expressing the highs $h_{0}$ and $h_{a}$ in terms of the angles $\beta$ and $\delta$ (Fig 1.), respectively.

$$
\begin{aligned}
& \mathrm{h}_{0}=l-l \cdot \cos (\beta)=l \cdot(1-\cos (\beta)) \\
& \mathrm{h}_{\mathrm{a}}=l-l \cdot \cos (\delta)=l \cdot(1-\cos (\delta))
\end{aligned}
$$

Eq. 5 is Eq. 2 rewritten in function of Eq. 3 and Eq. 4. At Eq. 5, the weigh (B) is expressed in $\mathrm{N}$, the length $(l)$ in meter and toughness $(\mathrm{W})$ in $\mathrm{N} \cdot \mathrm{m}$.

$$
\mathrm{W}=\mathrm{B} \cdot l \cdot(\cos (\beta)-\cos (\delta))
$$

Other papers tried to correlate the toughness of the wood with other properties.

Stolf et al. [13] studied the relation between the growth ring orientation and the toughness of four wood species (Parkia pendula, Eucalyptus grandis, Pinus elliottii and Corymbia citriodora) considering three different orientations, thus the orientation causes tensile strength in fibers close to the pitch, close to the bark and in the radial direction. Results showed that there is no significant variation in the toughness value according to the different growth ring orientation.

Almeida et al. [15] tested six wood species (Teca, Paricá, Pinus, Eucalipto, Jatobá and Angico) in order to determine their density. The work followed the procedures of the American Standard Code ASTM D5536:1995 [18] and of the Brazilian Standard Code ABNT NBR 7190:1997 [6] to determinate the toughness and density of the specimens. In order to find a relation between those properties, linear, quadratic and cubic polynomial regression models were used. They concluded that it is possible to determinate toughness as a function of the density. The cubic polynomial regression model proved to be more efficient for this purpose.

In the same area, Christoforo et al. [19] investigated the estimation wood toughness as a function of density using linear, quadratic and cubic regression models. In his studies, fifteen different Brazilian wood species were analyzed. They concluded that it is possible to estimate the toughness based on density and that the quadratic regression model presented the best results.

Pazos et al. [20] tested sixteen Mexican wood species in dry and saturated conditions. The test methods defined by ASTM D143:1999 [21] and by NF B51-009:1942 [22] were used, the first one being performed by an FPL type machine and the second by an Amsler type machine. Were observed that the saturated wood presents the highest values of toughness.

Beltrame et al. [23] tested ten samples of the Açoita-Cavalo wood specie (Luehea divaricata) with moisture content of $12 \%$ and saturated, in order to determine a correlation between the toughness of the wood and the humidity condition. Tests were carried out using recommendations from COPANT 458:1971 [24] and ASTM D5536:1995 [18]. They concluded that the tested wood presents greater impact resistance when saturated.

From the above, it is clear that greater technical knowledge of the applications and properties of Brazilian wood species are of major importance for the rationalization of its use [25-27].

The aim of this work is to find correlations that allow to estimate the toughness and the impact bending strength in function of the modulus of elasticity and the strength in the compression parallel to the grain of ten different Brazilian wood species. 


\section{Materials and Methods}

Brazilian wood species utilized on this work are natural species from certified area from Amazon Forest. Table 1 shows the studied Brazilian wood species, its scientific name and the strength class (SC) according to ABNT NBR 7190:1997 [6].

Specimens were prepared in Wood and Timber Structures Laboratory (LaMEM), Structural Engineering Department (SET), São Carlos Engineering School (EESC), São Paulo University (USP), Brazil. For the tests, the moisture content of all specimens were equal to $12 \%$, according to ABNT NBR 7190:1997 [6].

Table 1. Brazilian wood species

\begin{tabular}{ccc}
\hline Wood Specie & Scientific name & SC \\
\hline Cedro & Cedrella sp. & C20 \\
Cambará Rosa & Erisma uncinatum Warm & \\
\hline Cedrorana & Cedrelinga cateniformis & C30 \\
Catanudo & Calophyllum sp. & \\
\hline Cupiúba & Goupia glabra & C40 \\
Angelim Saia & Parkia spp. & C50 \\
\hline Tatajuba & Bagassa guianensis Aubl. & \\
Guaiçara & Luetzelburgia sp. & C60 \\
\hline Cumaru & Dipteryx odorata & \\
\hline Angelim Vermelho & Dinizia excelsa Ducke & \\
\hline
\end{tabular}

\subsection{Compression Parallel to the Grain Tests}

Compression parallel to the grain tests were conducted according to the Annex $B$ from the "ABNT NBR 7190:1997". For each Brazilian wood specie studied, 12 specimens with square cross-section (A) of $5.0 \mathrm{~cm}$ and $15 \mathrm{~cm}$ on grain direction (Fig. 2).

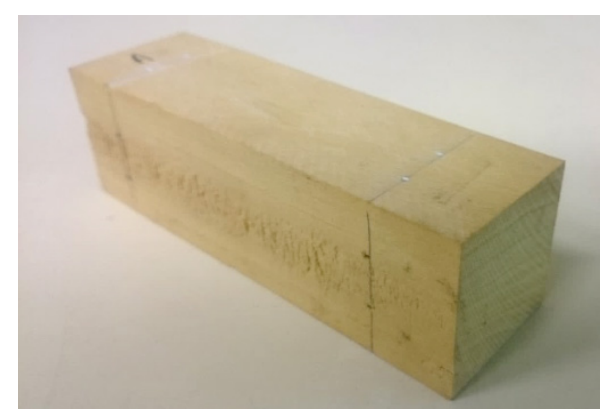

Figure 2. Tatajuba wood specie specimen to compression parallel to the grain test

Tests was conducted according to ABNT NBR 7190:1997 [6], at a AMSLER universal machine testing, with load capacity of 25 ton.

For each wood specie, were determined the compression parallel to the grain strength $\left(f_{\mathrm{c} 0}\right)(\mathrm{Eq} .6)$ and modulus of elasticity in compression parallel to grain loads $\left(\mathrm{E}_{\mathrm{c} 0}\right)$ (Eq. 7), where: $F_{\mathrm{c} 0}$ is the maximum compression force; $\sigma_{10 \%}$ and $\sigma_{50 \%}$ are the $10 \%$ and $50 \%$ correspondent to compression parallel to the grain strength estimated ( $\left.\mathrm{f}_{\mathrm{c} 0 \text {,est }}\right) ; \varepsilon_{10 \%}$ and $\varepsilon_{50 \%}$ are the specimen strain corresponding to $\sigma_{10 \%}$ and $\sigma_{50 \%}$, respectively.

$$
\begin{gathered}
\mathrm{f}_{\mathrm{c} 0}=\frac{\mathrm{F}_{\mathrm{c} 0}}{\mathrm{~A}} \\
\mathrm{E}_{\mathrm{c} 0}=\frac{\sigma_{50 \%}-\sigma_{10 \%}}{\varepsilon_{50 \%}-\varepsilon_{10 \%}}
\end{gathered}
$$

\subsection{Impact Bendind Tests}

Impact bending tests were conducted according to the Annex B from the ABNT NBR 7190:1997 [6]. Recommendations of ASTM D143:1999 [21] were adopted to determine wood toughness. For each wood specie studied, were fabricated 20 specimens with square cross-section of $2.0 \mathrm{~cm}$ and $30 \mathrm{~cm}$ on grain direction (Fig. 3).

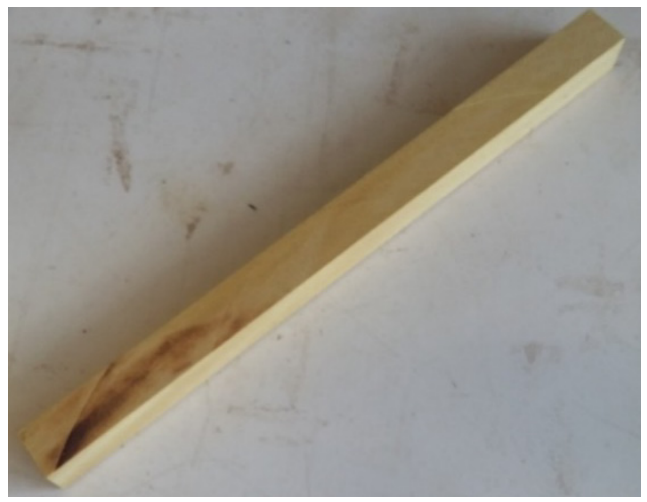

Figure 3. Tatajuba wood specie specimen to impact bendig test

Tests were conducted in a machine projected based on a FPL machine [21] (Fig. 4).

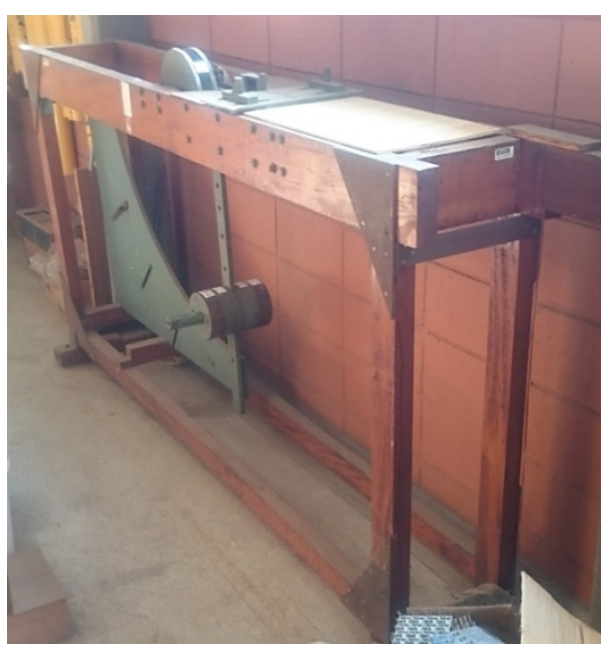

Figure 4. Machine used to impact bending tests

Energy absorbed by the specimen were determined according to the Eq. 5. Impact bending strength $\left(\mathrm{f}_{\mathrm{bw}}\right)$ were determined according to the Eq. 8 [6], were, $\mathrm{b}$ and $\mathrm{h}$ are square cross-section dimension of specimen, respectively.

$$
\mathrm{f}_{\mathrm{bw}}=\frac{1000 \cdot \mathrm{W}}{\mathrm{b} \cdot \mathrm{h}}
$$




\subsection{Statistical Analysis}

To correlate the values found for toughness (W) and for impact strength $\left(\mathrm{f}_{\mathrm{bw}}\right)$ with modulus of elasticity $\left(\mathrm{E}_{\mathrm{c} 0}\right)$ and strength $\left(f_{c 0}\right)$ in the compression parallel to the grain test, regression models were used (Eq. 9 until Eq. 12), where a and $\mathrm{b}$ are the parameters of the functions adjusted by the minimum squares method, $\mathrm{Y}$ is the independent variable and $\mathrm{X}$ is the dependent variable.

$$
\begin{array}{ll}
\mathrm{Y}=\mathrm{a}+\mathrm{b} \cdot \mathrm{x} & \text { Linear relation } \\
\mathrm{Y}=\mathrm{a} \cdot \mathrm{e}^{\mathrm{b} \cdot \mathrm{x}} & \text { Exponential relation } \\
\mathrm{Y}=\mathrm{a}+\mathrm{b} \cdot \ln (\mathrm{x}) & \text { Logarithmic relation } \\
\mathrm{Y}=\mathrm{a} \cdot \mathrm{x}^{\mathrm{b}} & \text { Geometric relation }
\end{array}
$$

In order to determine the quality of the regression models, these were evaluated according to analysis of variance (ANOVA); being the non-representativeness of the models admitted as null hypothesis and the representativeness as an alternative hypothesis. The models were considerate with $5 \%$ level of significance $(\alpha)$. For a P-value greater than the level of significance, it was considered that the model is not representative and for a $\mathrm{P}$-value less than $5 \%$, it was considered that the model is representative.

To evaluate the correlation between the independent variable and the dependent variable was used the coefficient of determination $\left(\mathrm{R}^{2}\right)$, this way it was possible to determine which of the models considered best fit the relation tested. The efficiency of the models was tested considering the wood species separately and as a group with all wood species.

\section{Results}

Table 2 until 11 presents the average values $(\bar{y})$, the coefficient of variation $(\mathrm{Cv})$, the minimum (Min) and the maximum (Max) values found for toughness $(\mathrm{W})$, strength in the impact bending test $\left(\mathrm{f}_{\mathrm{bw}}\right)$, modulus of elasticity $\left(\mathrm{E}_{\mathrm{c} 0}\right)$ and strength $\left(f_{c 0}\right)$ in compression parallel to the grain tests, for each one of the studied wood species.

Table 2. Results for Cedro wood specie

\begin{tabular}{ccccc}
\hline Stat. & $\mathbf{f}_{\mathrm{bw}}\left(\mathbf{k J} / \mathbf{m}^{\mathbf{2}}\right)$ & $\mathbf{W}(\mathbf{N} \cdot \mathbf{m})$ & $\mathbf{f}_{\mathrm{c} 0}(\mathbf{M P a})$ & $\mathbf{E}_{\mathbf{c} 0}(\mathbf{M P a})$ \\
\hline $\bar{y}$ & 19.46 & 7.78 & 31 & 8354 \\
$\mathrm{Cv}(\%)$ & 27.67 & 27.67 & 17.46 & 14.09 \\
Min & 10.75 & 4.30 & 27 & 6515 \\
$\operatorname{Max}$ & 27.43 & 10.97 & 44 & 10915 \\
\hline
\end{tabular}

Table 3. Results for Cambará Rosa wood specie

\begin{tabular}{ccccc}
\hline Stat. & $\mathbf{f}_{\mathrm{bw}}\left(\mathbf{k J} / \mathbf{m}^{2}\right)$ & $\mathbf{W}(\mathbf{N} \cdot \mathbf{m})$ & $\mathbf{f}_{\mathbf{c} 0}(\mathbf{M P a})$ & $\mathbf{E}_{\mathbf{c} \mathbf{0}}(\mathbf{M P a})$ \\
\hline $\bar{y}$ & 8.38 & 3.35 & 35 & 12967 \\
$\mathrm{Cv}(\%)$ & 18.73 & 18.73 & 14.93 & 18.00 \\
$\operatorname{Min}$ & 5.00 & 2.00 & 27 & 9732 \\
$\operatorname{Max}$ & 10.25 & 4.10 & 43 & 16960 \\
\hline
\end{tabular}

Table 4. Results for Cedrorana wood specie

\begin{tabular}{ccccc}
\hline Stat.s & $\mathbf{f}_{\mathbf{b w}}\left(\mathbf{k J} / \mathbf{m}^{2}\right)$ & $\mathbf{W}(\mathbf{N} \cdot \mathbf{m})$ & $\mathbf{f}_{\mathbf{c} 0}(\mathbf{M P a})$ & $\mathbf{E}_{\mathbf{c} 0}(\mathbf{M P a})$ \\
\hline $\bar{y}$ & 20.02 & 8.01 & 31 & 8962 \\
$\mathrm{Cv}(\%)$ & 25.33 & 25.33 & 14.43 & 8.54 \\
$\operatorname{Min}$ & 12.55 & 5.02 & 22 & 7894 \\
$\operatorname{Max}$ & 28.60 & 11.44 & 38 & 10305 \\
\hline
\end{tabular}

Table 5. Results for Catanudo wood specie

\begin{tabular}{ccccc}
\hline Stat. & $\mathbf{f}_{\mathrm{bw}}\left(\mathbf{k J} / \mathbf{m}^{2}\right)$ & $\mathbf{W}(\mathbf{N} \cdot \mathbf{m})$ & $\mathbf{f}_{\mathbf{c} 0}(\mathbf{M P a})$ & $\mathbf{E}_{\mathbf{c} 0}(\mathbf{M P a})$ \\
\hline $\bar{y}$ & 33.65 & 13.46 & 51 & 14279 \\
$\mathrm{Cv}(\%)$ & 23.53 & 23.53 & 6.78 & 12.58 \\
Min & 20.75 & 8.30 & 46 & 11708 \\
$\operatorname{Max}$ & 49.00 & 19.60 & 57 & 17950 \\
\hline
\end{tabular}

Table 6. Results for Cupiúba wood specie

\begin{tabular}{ccccc}
\hline Stat. & $\mathbf{f}_{\mathbf{b w}}\left(\mathbf{k J} / \mathbf{m}^{2}\right)$ & $\mathbf{W}(\mathbf{N} \cdot \mathbf{m})$ & $\mathbf{f}_{\mathbf{c} 0}(\mathbf{M P a})$ & $\mathbf{E}_{\mathbf{c} 0}(\mathbf{M P a})$ \\
\hline $\bar{y}$ & 15.35 & 6.14 & 57 & 12970 \\
$\mathrm{Cv}(\%)$ & 37.76 & 37.76 & 13.84 & 15.35 \\
$\operatorname{Min}$ & 8.00 & 3.20 & 49 & 9964 \\
$\operatorname{Max}$ & 25.50 & 10.20 & 74 & 16162 \\
\hline
\end{tabular}

Table 7. Results for Angelim Saia wood specie

\begin{tabular}{ccccc}
\hline Stat. & $\mathbf{f}_{\mathbf{b w}}\left(\mathbf{k J} / \mathbf{m}^{2}\right)$ & $\mathbf{W} \mathbf{( N \cdot m )}$ & $\mathbf{f}_{\mathbf{c} 0}(\mathbf{M P a})$ & $\mathbf{E}_{\mathbf{c} 0}(\mathbf{M P a})$ \\
\hline $\bar{y}$ & 11.38 & 4.55 & 63 & 19748 \\
$\mathrm{Cv}(\%)$ & 13.53 & 13.53 & 14.12 & 16.49 \\
$\operatorname{Min}$ & 8.50 & 3.40 & 47 & 13274 \\
$\operatorname{Max}$ & 13.25 & 5.30 & 76 & 25713 \\
\hline
\end{tabular}

Table 8. Results for Tatajuba wood specie

\begin{tabular}{ccccc}
\hline Stat. & $\mathbf{f}_{\mathbf{b w}}\left(\mathbf{k J} / \mathbf{m}^{2}\right)$ & $\mathbf{W} \mathbf{( N \cdot m )}$ & $\mathbf{f}_{\mathbf{c} 0}(\mathbf{M P a})$ & $\mathbf{E}_{\mathbf{c} 0}(\mathbf{M P a})$ \\
\hline $\bar{y}$ & 7.52 & 3.39 & 60 & 26723 \\
$\mathrm{Cv}(\%)$ & 45.24 & 45.92 & 7.11 & 25.22 \\
$\operatorname{Min}$ & 1.85 & 0.86 & 52 & 20763 \\
$\operatorname{Max}$ & 13.44 & 5.98 & 66 & 46958 \\
\hline
\end{tabular}

Table 9. Results for Guaiçara wood specie

\begin{tabular}{ccccc}
\hline Stat. & $\mathbf{f}_{\mathbf{b w}}\left(\mathbf{k J} / \mathbf{m}^{2}\right)$ & $\mathbf{W}(\mathbf{N} \cdot \mathbf{m})$ & $\mathbf{f}_{\mathbf{c} 0}(\mathbf{M P a})$ & $\mathbf{E}_{\mathbf{c} 0}(\mathbf{M P a})$ \\
\hline $\bar{y}$ & 44.98 & 17.99 & 71 & 15301 \\
$\mathrm{Cv}(\%)$ & 19.64 & 19.64 & 12.57 & 15.80 \\
$\operatorname{Min}$ & 27.50 & 11.00 & 58 & 11073 \\
$\operatorname{Max}$ & 61.00 & 24.40 & 84 & 17959 \\
\hline
\end{tabular}

Table 10. Results for Cumaru wood specie

\begin{tabular}{ccccc}
\hline Stat. & $\mathbf{f}_{\mathrm{bw}}\left(\mathbf{k J} / \mathbf{m}^{2}\right)$ & $\mathbf{W} \mathbf{( N \cdot \mathbf { m } )}$ & $\mathbf{f}_{\mathbf{c} 0}(\mathbf{M P a})$ & $\mathbf{E}_{\mathbf{c} 0}(\mathbf{M P a})$ \\
\hline $\bar{y}$ & 57.32 & 22.93 & 93 & 23002 \\
$\mathrm{Cv}(\%)$ & 20.42 & 20.42 & 5.64 & 10.76 \\
$\operatorname{Min}$ & 41.75 & 16.70 & 85 & 18480 \\
$\operatorname{Max}$ & 75.25 & 30.10 & 103 & 26550 \\
\hline
\end{tabular}


Table 11. Results for Angelim Vermelho wood specie

\begin{tabular}{ccccc}
\hline Stat. & $\mathbf{f}_{\mathrm{bw}}\left(\mathbf{k J} / \mathbf{m}^{2}\right)$ & $\mathbf{W}(\mathbf{N} \cdot \mathbf{m})$ & $\mathbf{f}_{\mathbf{c} 0}(\mathbf{M P a})$ & $\mathbf{E}_{\mathbf{c} 0}(\mathbf{M P a})$ \\
\hline $\bar{y}$ & 49.52 & 19.81 & 78 & 16695 \\
$\mathrm{Cv}(\%)$ & 34.93 & 34.93 & 7.58 & 17.82 \\
Min & 25.25 & 10.10 & 66 & 9494 \\
$\operatorname{Max}$ & 75.25 & 30.10 & 90 & 20935 \\
\hline
\end{tabular}

Regression models were used in order to find a correlation between the determined properties. Linear, exponential, logarithmic and geometric relationships between data were analyzed to find a function that best represents their behavior. Tables 12 and 13 presents the functions determined for the studied species as well as for each combination of the properties analyzed.

Table 12. Regression models to estimate $\mathrm{W}$ and $\mathrm{f}_{\mathrm{bw}}$ (Part $\mathrm{A}$ )

\begin{tabular}{|c|c|c|c|c|c|c|}
\hline Wood Species & $Y(x)$ & Relation & $\mathbf{a}$ & $\mathbf{b}$ & $\mathbf{R}^{2}(\%)$ & P-value \\
\hline \multirow{4}{*}{ Cedro } & $\mathrm{W}\left(\mathrm{E}_{\mathrm{c} 0}\right)$ & Exponential & 7.9497 & 0.0000 & 0.08 & 0.9305 \\
\hline & $\mathrm{W}\left(\mathrm{f}_{\mathrm{c} 0}\right)$ & Logarithmic & 18.2540 & -3.0483 & 5.11 & 0.4797 \\
\hline & $\mathrm{f}_{\mathrm{bw}}\left(\mathrm{E}_{\mathrm{c} 0}\right)$ & Exponential & 19.8763 & 0.0000 & 0.08 & 0.9306 \\
\hline & $\mathrm{f}_{\mathrm{bw}}\left(\mathrm{f}_{\mathrm{c} 0}\right)$ & Logarithmic & 45.6345 & -7.6196 & 5.11 & 0.4798 \\
\hline \multirow{4}{*}{ Cambará Rosa } & $\mathrm{W}\left(\mathrm{E}_{\mathrm{c} 0}\right)$ & Logarithmic & 17.8705 & -2.0000 & 19.54 & 0.1501 \\
\hline & $\mathrm{W}\left(\mathrm{f}_{\mathrm{c} 0}\right)$ & Logarithmic & 5.0000 & 0.0000 & 0.66 & 0.8012 \\
\hline & $\mathrm{f}_{\mathrm{bw}}\left(\mathrm{E}_{\mathrm{c} 0}\right)$ & Logarithmic & 45.0000 & -4.0000 & 19.54 & 0.1501 \\
\hline & $\mathrm{f}_{\mathrm{bw}}\left(\mathrm{f}_{\mathrm{c} 0}\right)$ & Logarithmic & 11.0000 & -1.0000 & 0.66 & 0.8012 \\
\hline \multirow{4}{*}{ Cedrorana } & $\mathrm{W}\left(\mathrm{E}_{\mathrm{c} 0}\right)$ & Exponential & 21.6899 & -0.0001 & 11.20 & 0.2876 \\
\hline & $\mathrm{W}\left(\mathrm{f}_{\mathrm{c} 0}\right)$ & Logarithmic & 43.9581 & -10.5000 & 61.75 & 0.0024 \\
\hline & $\mathrm{f}_{\mathrm{bw}}\left(\mathrm{E}_{\mathrm{c} 0}\right)$ & Exponential & 54.2564 & -0.0001 & 11.21 & 0.2873 \\
\hline & $\mathrm{f}_{\mathrm{bw}}\left(\mathrm{f}_{\mathrm{c} 0}\right)$ & Logarithmic & 109.9016 & -26.2515 & 61.75 & 0.0024 \\
\hline \multirow{4}{*}{ Catanudo } & $\mathrm{W}\left(\mathrm{E}_{\mathrm{c} 0}\right)$ & Logarithmic & -150.7124 & 17.1735 & 44.54 & 0.0177 \\
\hline & $\mathrm{W}\left(\mathrm{f}_{\mathrm{c} 0}\right)$ & Exponential & 6.3903 & 0.0142 & 4.10 & 0.5279 \\
\hline & $\mathrm{f}_{\mathrm{bw}}\left(\mathrm{E}_{\mathrm{c} 0}\right)$ & Logarithmic & -376.7810 & 42.9338 & 44.54 & 0.0177 \\
\hline & $\mathrm{f}_{\mathrm{bw}}\left(\mathrm{f}_{\mathrm{c} 0}\right)$ & Exponential & 15.9757 & 0.0142 & 4.10 & 0.5279 \\
\hline \multirow{4}{*}{ Cupiúba } & $\mathrm{W}\left(\mathrm{E}_{\mathrm{c} 0}\right)$ & Geometric & 1266.6125 & -0.5702 & 5.36 & 0.4689 \\
\hline & $\mathrm{W}\left(\mathrm{f}_{\mathrm{c} 0}\right)$ & Geometric & 0.0340 & 1.2692 & 19.58 & 0.1497 \\
\hline & $\mathrm{f}_{\mathrm{bw}}\left(\mathrm{E}_{\mathrm{c} 0}\right)$ & Geometric & 3166.5314 & -0.5702 & 5.36 & 0.4689 \\
\hline & $\mathrm{f}_{\mathrm{bw}}\left(\mathrm{f}_{\mathrm{c} 0}\right)$ & Geometric & 0.0851 & 1.2692 & 19.58 & 0.1497 \\
\hline \multirow{4}{*}{ Angelim Saia } & $\mathrm{W}\left(\mathrm{E}_{\mathrm{c} 0}\right)$ & Logarithmic & -8.6988 & 1.3413 & 14.62 & 0.2199 \\
\hline & $\mathrm{W}\left(\mathrm{f}_{\mathrm{c} 0}\right)$ & Logarithmic & 2.4349 & 0.5117 & 1.54 & 0.7009 \\
\hline & $\mathrm{f}_{\mathrm{bw}}\left(\mathrm{E}_{\mathrm{c} 0}\right)$ & Logarithmic & -21.7469 & 3.3533 & 14.62 & 0.2199 \\
\hline & $\mathrm{f}_{\mathrm{bw}}\left(\mathrm{f}_{\mathrm{c} 0}\right)$ & Logarithmic & 6.0873 & 1.2793 & 1.54 & 0.7009 \\
\hline \multirow{4}{*}{ Tatajuba } & $\mathrm{W}\left(\mathrm{E}_{\mathrm{c} 0}\right)$ & Linear & 0.6166 & 0.0001 & 20.19 & 0.1427 \\
\hline & $\mathrm{W}\left(\mathrm{f}_{\mathrm{c} 0}\right)$ & Exponential & 272.9467 & -0.0747 & 34.71 & 0.0438 \\
\hline & $\mathrm{f}_{\mathrm{bw}}\left(\mathrm{E}_{\mathrm{c} 0}\right)$ & Linear & 1.6069 & 0.0002 & 19.21 & 0.154 \\
\hline & $\mathrm{f}_{\mathrm{bw}}\left(\mathrm{f}_{\mathrm{c} 0}\right)$ & Exponential & 615.5317 & -0.0749 & 35.00 & 0.0427 \\
\hline \multirow{4}{*}{ Guaiçara } & $\mathrm{W}\left(\mathrm{E}_{\mathrm{c} 0}\right)$ & Geometric & 3.3118 & 0.1739 & 1.93 & 0.6667 \\
\hline & $\mathrm{W}\left(\mathrm{f}_{\mathrm{c} 0}\right)$ & Geometric & 9.9430 & 0.1346 & 0.67 & 0.801 \\
\hline & $\mathrm{f}_{\mathrm{bw}}\left(\mathrm{E}_{\mathrm{c} 0}\right)$ & Geometric & 8.2796 & 0.1739 & 1.93 & 0.6667 \\
\hline & $\mathrm{f}_{\mathrm{bw}}\left(\mathrm{f}_{\mathrm{c} 0}\right)$ & Geometric & 24.8574 & 0.1346 & 0.67 & 0.801 \\
\hline
\end{tabular}


Table 13. Regression models to estimate $\mathrm{W}$ and $\mathrm{f}_{\mathrm{bw}}$ (Part B)

\begin{tabular}{ccccccc}
\hline Wood Species & $\mathbf{Y}(\mathbf{x})$ & Relation & $\mathbf{a}$ & $\mathbf{b}$ & $\mathbf{R}^{\mathbf{2}} \mathbf{( \% )}$ & P-value \\
\hline \multirow{4}{*}{ Cumaru } & $\mathrm{W}\left(\mathrm{E}_{\mathrm{c} 0}\right)$ & Linear & 28.4443 & -0.0002 & 1.61 & 0.6944 \\
& $\mathrm{~W}\left(\mathrm{f}_{\mathrm{c} 0}\right)$ & Linear & 5.8428 & 0.1832 & 4.24 & 0.521 \\
& $\mathrm{f}_{\mathrm{bw}}\left(\mathrm{E}_{\mathrm{c} 0}\right)$ & Linear & 71.1107 & -0.0006 & 1.61 & 0.6944 \\
& $\mathrm{f}_{\mathrm{bw}}\left(\mathrm{f}_{\mathrm{c} 0}\right)$ & Linear & 14.6071 & 0.4580 & 4.24 & 0.521 \\
\hline \multirow{3}{*}{ Angelim Vermelho } & $\mathrm{W}\left(\mathrm{E}_{\mathrm{c} 0}\right)$ & Geometric & 1.6536 & 0.2496 & 1.92 & 0.6676 \\
& $\mathrm{~W}\left(\mathrm{f}_{\mathrm{c} 0}\right)$ & Logarithmic & 157.2140 & -31.5969 & 12.10 & 0.2679 \\
& $\mathrm{f}_{\mathrm{bw}}\left(\mathrm{E}_{\mathrm{c} 0}\right)$ & Geometric & 4.1341 & 0.2496 & 1.92 & 0.6676 \\
& $\mathrm{f}_{\mathrm{bw}}\left(\mathrm{f}_{\mathrm{c} 0}\right)$ & Logarithmic & 393.0351 & -78.9923 & 12.10 & 0.2679 \\
\hline \multirow{6}{*}{ All species } & $\mathrm{W}\left(\mathrm{E}_{\mathrm{c} 0)}\right)$ & Logarithmic & -25.8304 & 3.8092 & 3.71 & 0.0351 \\
& $\mathrm{~W}\left(\mathrm{f}_{\mathrm{c} 0}\right)$ & Linear & -2.1526 & 0.2259 & 37.42 & 0.0000 \\
& $\mathrm{f}_{\mathrm{bw}}\left(\mathrm{E}_{\mathrm{c} 0}\right)$ & Logarithmic & -60.7643 & 9.1160 & 3.36 & 0.0448 \\
& $\mathrm{f}_{\mathrm{bw}}\left(\mathrm{f}_{\mathrm{c} 0}\right)$ & Linear & -5.4467 & 0.5641 & 37.01 & 0.0000 \\
\hline
\end{tabular}

\section{Discussions}

Cumaru wood specie present better average value to $\mathrm{W}$ and $\mathrm{f}_{\mathrm{bw}}$ equal to $57.32 \mathrm{~kJ} / \mathrm{m}^{2}$ and $22.93 \mathrm{~N} \cdot \mathrm{m}$, respectively. Lower average values for $\mathrm{W}$ and $\mathrm{f}_{\mathrm{bw}}$ were found to Tatajuba wood specie $\left(\mathrm{W}=7.52 \mathrm{~kJ} / \mathrm{m}^{2}\right)$ and Cambará Rosa wood specie $\left(\mathrm{f}_{\mathrm{bw}}=3.35 \mathrm{~N} \cdot \mathrm{m}\right)$.

Average values of $\mathrm{W}$ and $\mathrm{f}_{\mathrm{bw}}$ did not follow the values of the strength classes of the wood species (based on the compression parallel to the grain strength characteristic [6]), when comparing Cedro and Tatajuba wood species or Cedro and Cupiúba wood species.

Better regression model found in this research was logarithmic relation to Cedrorana wood specie, between $\mathrm{W}$ as function of $f_{c 0}$ and $f_{b w}$ as function of $f_{c 0}$, both with coefficient of determination $\left(\mathrm{R}^{2}\right)$ equal to $61,75 \%$.

Others coefficients of determination, found for the wood species studied in this research and for the regression models adopted, were bellow to $40 \%$ (minimum: $\mathrm{R}^{2}=0.08 \%$ for Cedro to $\mathrm{W}$ as function of $\mathrm{E}_{\mathrm{c} 0}$; maximum: $\mathrm{R}^{2}=35.00 \%$ for Tatajuba to $\mathrm{f}_{\mathrm{bw}}$ as function of $\mathrm{f}_{\mathrm{c} 0}$ ).

Cedro and Cumaru wood species was classified as C20 and $\mathrm{C} 60$ on the strength classes, respectively, according to ABNT NBR 7190:1997 [6], but, both wood species don't present good relation between stiffness and strength properties in compression parallel to the grain loads and $\mathrm{W}$ or $\mathrm{f}_{\mathrm{bw}}$.

For regression models to group involving all wood species, better coefficient of determination was to $\mathrm{W}$ as function of $\mathrm{f}_{\mathrm{c} 0}$, using a linear relation $\left(\mathrm{R}^{2}=37.42 \%\right)$.

Other researches using density as estimator of mechanical properties of wood [26, 28] present better coefficient of determination to regression models. One possibility would be to use the density of wood species of this research as an estimator, to consider the variability of the wood, even within the same strength class.
More researches about correlations between properties of wood is very important to rational use at several purposes and knowledge of properties of Brazilian Tropical wood species.

\section{Conclusions}

Higher and lower average values of $\mathrm{W}$ was determined to Cumaru wood specie $\left(57.32 \mathrm{~kJ} / \mathrm{m}^{2}\right)$ and Tatajuba wood specie $\left(\mathrm{W}=7.52 \mathrm{~kJ} / \mathrm{m}^{2}\right)$. $\mathrm{f}_{\mathrm{bw}}$ average values was found to Cumaru wood specie $\left(f_{b w}=22.93 \mathrm{~N} \cdot \mathrm{m}\right)$ and Cambará Rosa wood specie $\left(\mathrm{f}_{\mathrm{bw}}=3,35 \mathrm{~N} \cdot \mathrm{m}\right)$, as higher and lower average values, respectively.

Cedrorana wood specie present better regression model to estimate $\mathrm{W}$ and $\mathrm{f}_{\mathrm{bw}}$ as function of $\mathrm{f}_{\mathrm{c} 0}$, for both, $\mathrm{R}^{2}=61.75 \%$.

Results of the statistical analysis revealed led to the conclusion that there is no correlation between the proposed properties for the analyzed species.

\section{ACKNOWLEDGMENTS}

Authors thank to Wood and Timber Structures Laboratory (LaMEM), Structural Engineering Department (SET), São Carlos Engineering School (EESC), São Paulo University, by the materials and resources used in this research.

\section{REFERENCES}

[1] Grobério, M. P.; Lahr, F. A. R. Indicações para o emprego da madeira de espécies tropicais do Brasil. Madeira: Arquitetura e Engenharia, 8 (2002) 1-11.

[2] Forest Stewardship Council (FSC). FSC: Facts \& Figures. 
FSC, 2017:

$<$ https://br.fsc.org/pt-br/fsc-brasil/fatos-e-nmeros $>$. 09 June 2017.

[3] Pereira, D.; Santos, D.; Vedoveto, M.; Guimarães, J.; Veríssimo, A. Fatos Florestais da Amazônia 2010. Belém: Imazon, 2010.

[4] Velloso, J. G. Diretrizes para construções em madeira no sistema plataforma. 2010. 103 p. Dissertação (Mestrado em Engenharia Civil) - Universidade Federal de Santa Catarina, Florianópolis, 2010.

[5] Calil Junior, C.; Molina, J. C. Coberturas em estruturas de madeira: exemplos de cálculo. São Paulo: Pini, 2010.

[6] ABNT NBR 7190:1997. Projeto de estruturas de madeira. Rio de Janeiro, 1997.

[7] Kollmann, F. F. P.; Côté, W. A. Principles of wood science and technology: solid wood. Berlin: Springer-Verlag, 1968.

[8] Bodig, J.; Jayne, B. A. Mechanics of wood and wood composites. Malabar: Krieger Publishing Company, 1993.

[9] Calil Junior, C.; Lahr, F. A. R.; Dias, A. A. Dimensionamento de elementos estruturais de madeira. Barueri: Manole, 2003.

[10] Cheung, A. B.; Scaliante, R. M.; Lindquist, M.; Christoforo, A. L.; Calil Junior, C. Confiabilidade estrutural de uma ponte protendida de madeira considerando o tráfego real. Ambiente Construido, 17:2 (2017) 221-232.

[11] Icimoto, F. H. Dormentes em madeira laminada colada de Pinus oocarpa. 2013. 125 p. Dissertação (Mestrado em Ciência e Engenharia de Materiais) - Universidade de São Paulo, São Carlos, 2013.

[12] Scaliante, R. M.; Almeida, D. H.; Calil Junior, C.; Christoforo, A. L.; Lahr, F. A. R. Brazilian criteria ultimate limit states verifications for glulam girders and glulam transversal deck panels bridges. International Journal of Materials Engineering, 6:4 (2016) 134-145.

[13] Stolf, D. O.; Bertolini, M. S.; Almeida, D. H.; Silva, D. A. L.; Panzera, T. H.; Christoforo, A. L.; Lahr, F. A. R. Influence of growth ring orientation of some wood species to obtain toughness. Revista Escola de Minas, $28: 3$ (2015) 265-271.

[14] Stolf, D. O.; Bertolini, M. S.; Ferro, F. S.; Christoforo, A. L.; Lahr, F. A. R. Influência do teor de umidade na propriedade de tenacidade de espécies florestais. Revista Floresta e Ambiental, $21: 4$ (2014) 501-508.

[15] Almeida, D. H.; Scaliante, R. M.; Christoforo, A. L.; Varanda, L. D.; Lahr, F. A. R.; Dias, A. A.; Calil Junior, C. Tenacidade da madeira como função da densidade aparente. Revista Árvore, 38:1 (2014) 203-207.
[16] Adamopoulos, S.; Passialis, C. Relationship of toughness and modulus of elasticity in static bending of small clear spruce wood specimens. European Journal of Wood and Wood Products, 68:1 (2010), 109-111.

[17] Askeland, D. R.; Phulé, P. P. Ciência e engenharia dos materiais. São Paulo: Cengage Learning, 2008.

[18] ASTM D5536:1995. Standard practice for sampling forest trees for determination of clear wood properties. Philadelphia, 1995.

[19] Christoforo, A. L.; Silva, S. A. M.; Panzera, T. H.; Lahr, F. A. R. Estimative of wooden toughness by the apparent density and bending strength. International Journal of Materials Engineering, 4:2 (2014) 49-55.

[20] Pazos, G. B.; Morales, R. P. Z.; Candelaria, V. R. O.; Báez, A. G.; Salazar, J. A. H. Correlación de los resultados de impacto o tenacidad de 16 maderas mexicanas utilizando dos métodos de prueba. Madera y Bosques. 9:1 (2003) 55-70.

[21] ASTM D143:1999. Standard test methods for small clear specimens of timber. Philadelphia, 1999.

[22] NF B51-009:1942. Bois essai de choc ou flexion dynamique. Paris, 1942.

[23] Beltrame, R.; Gatto, D. A.; Modes, K. S.; Stangerlin, D. M.; Trevisan, R.; Haselein, C. R. Resistência ao impacto da madeira de Açoita-Cavalo em diferentes condições de umidade. Cerne, 16:4 (2010) 499-504.

[24] COPANT 458:1971. Maderas: selección y colección de muestras. La Paz, 1971.

[25] Almeida, T. H.; Christoforo, A. L.; Lahr, F. A. R. Study of dimensional stability of Brazilian tropical wood species. Chisinau: Lambert Academic Publishing, 2017.

[26] Almeida, T. H.; Almeida, D. H.; Araújo, V. A.; Silva, S. A. M.; Christoforo, A. L.; Lahr, F. A. R. Density as estimator of dimensional stability quantities of Brazilian tropical woods. BioResources, 12:3 (2017) 6579-6590.

[27] Steege, H.; Vaessen, R. W.; López, D. C.; Sabatier, D.; Antonelli, A.; Oliveira, S. M.; Pitman, N. C. A.; Jorgensen, P. M.; Salomão, R. P. The discovery of the Amazonian tree flora with an update checklist of all known tree taxa. Scientific Reports, 6(29549) 1-15.

[28] Almeida, T. H.; Almeida, D. H.; Christoforo, A. L.; Chahud, E.; Branco, L. A. M. N.; Lahr, F. A. R. Density as estimator of strength in compression parallel to the grain in wood. International Journal of Materials Engineering, 6:3 (2016) $67-71$. 